\title{
MATERIAL FLOWS IN PRIMARY WOOD PROCESSING IN SLOVAKIA
}

\author{
Ján Parobek \\ Technical University in Zvolen, Faculty of Wood Sciences and Technology, Department of Marketing, Trade and \\ World Forestry, T. G. Masaryka 24, 96053 Zvolen, Slovakia, parobek @ tuzvo.sk \\ Hubert Paluš \\ Technical University in Zvolen, Faculty of Wood Sciences and Technology, Department of Marketing, Trade and \\ World Forestry, T. G. Masaryka 24, 96053 Zvolen, Slovakia, palus@ tuzvo.sk
}

Keywords: wood flows, wood resources, logistics

Abstract: Material flow analysis was used to reveal and quantify relations between the resources and the primary uses of wood. The paper deal with the analysis of raw wood flows in Slovakia in two approaches to wood flow modelling were utilised - wood balance and wood resource balance. Wood balance was presented to demonstrate a general view of the resources and primary uses of roundwood without analysing internal flows. The wood resource balance, as a more detailed analysis, takes into account the uses of wood as a material and also the by-products and waste generated by the production that could be used as inputs for further uses in wood processing or energy sectors. The latter balance was compiled using available official statistics supplemented by a questionnaire to estimate missing data for waste streams with a total consumption of 10.78 mil. $\mathrm{m}^{3}$ roundwood.

\section{Introduction}

The path of raw wood material from its production to giving the final product to a consumer is relatively long, as it passes several stages of production and different types of markets until the final product fulfils the needs of the consumers. Before reaching the end-user, these stages include leaving the forest, primary wood processing, secondary wood processing, and subsequent wood-using industries. Within these stages, raw wood material is transformed into primary processed intermediate products (sawn wood, pulp), secondary processed products (furniture, construction, and joinery), and then has a role in the final production of different industries related to the use of wood (e.g., construction). The domestic wood processing industry in the Slovak Republic is the major customer of the products of the forestry sector, and roundwood represents the main material input for this sector [1]. Similar links exist between the wood processing industry and other sectors that are dependent on wood products. Material flow analysis (MFA) can be used for the quantification and modelling of wood flows. The analysis process includes the gathering of information and requires market experience and recognition of mutual relations in the "forest - wood - end-user" chain.

EUROSTAT [2] distinguishes and explains the three basic dimensions of material flows: territorial dimension, product chain or life cycle dimension and the product dimension. Different approaches to material flow analysis and modelling have been used by e.g. [3], [4], [5], [6], [7]. The analysis of material flows can be also used as an analytical and modelling tool for different areas and sectors e.g., material balances of corporations and urban regions in industrialized countries [8], regional wood management [9], and the generation of waste in regional systems [10].

The analysis of wood flows enables one to determine a balance between the production and the use of wood in the country. The analysis results reveal relationships between the production, quality, and availability of data, the balance of foreign trade, and the importance of wood in domestic consumption. Wood flow analysis is focused on all uses of wood and takes into account by-products and waste generated by processing the material input for further use. Both sides of the balance, the resources and the use side, are specific, as they incorporate different markets and products; therefore, it is necessary to examine each side individually. The overall structure of the balance is not constant and may vary depending on the uses of wood and wood products. In most cases, the balance includes such uses of wood for which there are no official statistics available, and the total consumption therefore cannot be simply calculated. Consequently, the consumption of wood may be much higher than indicated by official statistics. Wood balances and material flow analyses have been developed in a number of countries [11], [3], [12], [13]. In general, wood flow analysis is focused more on resources than on products. Official data are not recorded for individual distribution channels in different sectors and products purchased by individual consumers. For these reasons, the analysis of wood flows highlights the need for empirical research and the use of empirically collected data. The balance can either be simply constructed as "wood balance," or it can reflect a complicated structure of market and material flows as 
MATERIAL FLOWS IN PRIMARY WOOD PROCESSING IN SLOVAKIA

Ján Parobek; Hubert Paluš

"wood resource balance". This easily helps analysts to obtain the missing information and integrates information from the forestry sector, wood processing industry, and energy sector. The approach thus enables one to control and monitor wood flows at a national and international level. Emerging and developing ways of using wood can be easily integrated into the existing flows [14].

The objective of this work was to analyse material flows in primary wood processing in Slovakia. For these purposes, two particular approaches were used - wood balance and wood resource balance.

\section{Material and Methods}

A single wood balance presents a global view of the resources and primary uses of roundwood in Slovakia. The main categories of resources are represented by the domestic roundwood production and imports, and the main uses by the domestic roundwood consumption and exports. The resource side is complemented by the recycled material and stock decrease, and the use side by the stocks increase. An increase in stocks causes a decrease in consumption, and vice-versa. The availability and consistency of data represent a limiting factor for the construction of the wood balance. Available data for 2013 from the FAOSTAT database [15] and the reports on forestry in Slovakia [16] were used. To achieve the state of wood balance, the resources should equal the uses. However, there were no data available on domestic consumption; therefore, it was deducted from the volumes of roundwood production and foreign trade.

The wood resource balance provides a detailed analysis of wood and wood products flows. Unlike the wood balance, which takes into account only uses of wood as a material, the wood resource balance is focused on different uses within the internal environment of the sector. First of all, it takes into consideration by-products and waste generated by the production for use as inputs in wood processing or in the energy sector. The main categories of resources are i) forest woody biomass, ii) used material, iii) other woody biomass, iv) wood processing residues and v) processed wood fuel. The main categories of uses consist of i) wood processing industry (material stream) and ii) energy use (waste stream).

The quality of the final wood resource balance depends directly on the quality and availability of data on wood production and use in individual sectors. Generally, the availability of data on consumption is usually poor, and detailed data do not exist. Empirical research and expert estimations based on the available production data are commonly used to obtain the missing data. Under current conditions, wood resource balance data can be compiled as a mix of officially published and empirically collected data. Official statistics are available for highly concentrated sectors such as the pulp and paper industry.
However, certain sectors of the wood processing industry, such as the sawmill industry, are poorly concentrated; thus, access to data is complicated. Therefore, to estimate the material flows the main streams of primary wood processing and utilization were only considered, in particular sawmilling industry, veneer and plywood production, particleboard and fibre board production, processed wood fuel, pulp and paper industry, energy biomass for power and heat, industrial internal use, and private households. To quantify flows and balances in a single measurement unit $\left(\mathrm{m}^{3}\right)$, the UNECE/FAO [17] official input/output ratios for Slovakia were used.

\section{Results and Discussion}

The primary wood resources are represented by the domestic roundwood production of $8.06 \mathrm{mil} . \mathrm{m}^{3}$. The actual level of wood supply is to a certain extent affected by the binding provisions of the valid management plans and thus it is an inelastic supply. The final level of wood consumption and market changes are the reflection of the influence of a range of social, economic and demographic factors, industry structure and the level of industry development. Wood supply is affected by the factors such as available cut, accidental felling, wood stock from previous periods, ownership structure, own consumption, wood price, price of production factors, valid legislation, etc. The volume of the actual felling is relatively stable from a long-term perspective, though a share of accidental felling is quite high (up to $70 \%$ ). The resource side is complemented by the import of roundwood $(0.922 \mathrm{mil}$. $\mathrm{m}^{3}$ ) and is represented mostly by the import of nonconiferous pulpwood used for pulp production, and by the recycled material calculated as the domestic production plus import and reduced by export.

The total resources were 8.984 mil. $\mathrm{m}^{3}$ roundwood equivalents. The use side of the balance is represented by the roundwood export, which was 3.122 mil. $\mathrm{m}^{3}$. The share of roundwood exports for is relatively high (35\%) and significantly reduces the domestic availability of certain roundwood assortments. The volume of domestic consumption $\left(5.862 \mathrm{mil} . \mathrm{m}^{3}\right.$ ) was deducted from the volumes of roundwood production and foreign trade. The wood balance presents a global view of the resources and primary uses of roundwood in Slovakia and is illustrated in Table 1. Because of the unavailability of data, we do not consider the stock changes. 
MATERIAL FLOWS IN PRIMARY WOOD PROCESSING IN SLOVAKIA

Ján Parobek; Hubert Paluš

Table 1 Wood Balance in Slovakia $\left(\mathrm{m}^{3}\right)$

\begin{tabular}{|l|r|l|r|}
\hline \multicolumn{2}{|c|}{ Sources } & \multicolumn{2}{c|}{ Use } \\
\hline $\begin{array}{l}\text { Roundwood } \\
\text { production } \\
\text { Import }\end{array}$ & 8062587 & & 312200 \\
Used paper* & 922000 & Export & $\begin{array}{r}586288 \\
4\end{array}$ \\
\hline Total sources & 10782446 & Total uses & 10782446 \\
\hline
\end{tabular}

The wood resource analysis shows that the total resources were 8.731 mil. $\mathrm{m}^{3}$ roundwood (Table 2). Roundwood volume on the resource side is supplemented by wood processing residues consisting mainly of sawmill residues and black liquor. These residues account for $16 \%$ of the total resources. The majority of residues $(1.3 \mathrm{mil}$. $\mathrm{m}^{3}$ roundwood equivalents) was produced by the sawmill industry.

Taking into account the overall estimated data, almost $83 \%$ of all resources used in Slovakia originated in forest biomass, $17 \%$ were from industry waste. On the other hand, over $84 \%$ of resources were used industrially, while nearly $16 \%$ were used for energy purposes.

At the same time, the sawmill industry is the key producer of wood products on the use side of the balance, followed by the production of pulp and wood-based panels. The consumption of energy wood in its different forms was estimated over $3 \mathrm{mil} . \mathrm{m}^{3}$. This overall estimate comprises energy wood for households, power, and heat production, as well as direct consumption in the wood processing industry. Wood fuel industry is a very specific sector, with the production of $31,000 \mathrm{~m}^{3}$ roundwood equivalents. Most of this production, however, is exported from the country, and only a small portion occurs on the resource side.

The sawmill industry with its production of $1.43 \mathrm{mil}$. $\mathrm{m}^{3}$ sawnwoods represents the main consumer of roundwood (coniferous) as well as the main producer of wood products in Slovakia. The final volume of production by the pulp and paper industry is important consumer of non-coniferous pulpwood. However, because of the intensive material input/output ratio, the final production was only 0.7 mil. t. Most of this production is represented by chemical pulp, where the input/output ratio is the highest (4.5).
Table 2 Wood Resource Balance

\begin{tabular}{|c|c|c|c|c|}
\hline Resources & $\left(\mathrm{m}^{3}\right)$ & Use & $\left(\mathrm{m}^{3}, \mathrm{t}\right)$ & \\
\hline 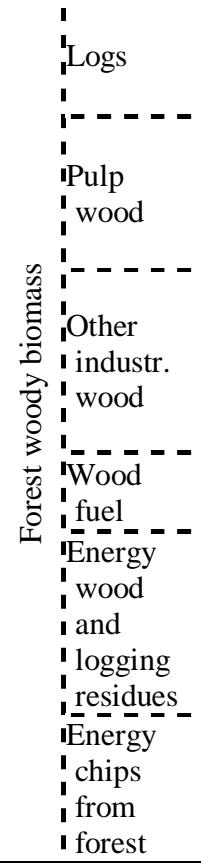 & 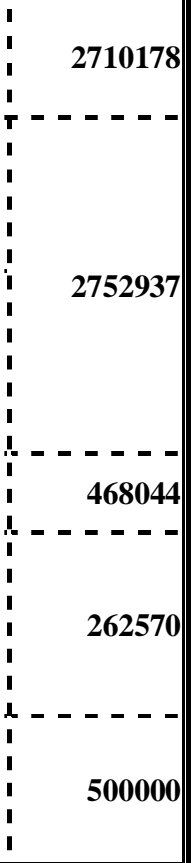 & \begin{tabular}{|r} 
awmill industry \\
eneer, plywood \\
and other large \\
boards \\
production \\
Particleboard \\
and fibre board \\
production \\
Processed \\
wood fuel \\
production
\end{tabular} & : & 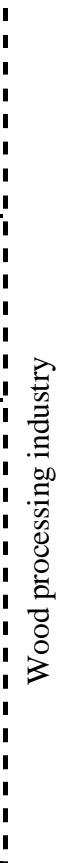 \\
\hline 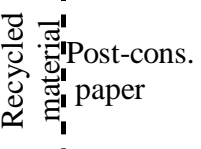 & i & $\begin{array}{r}\text { Pulp and paper } \\
\text { industry }\end{array}$ & 700000 & \\
\hline 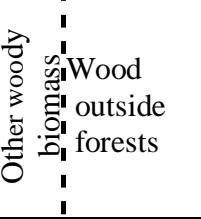 & $\begin{array}{l}\text { i } \\
1 \\
1 \\
1 \\
1\end{array}$ & $\begin{array}{r} \\
\text { Energy } \\
\text { biomass for }\end{array}$ & 1134000 & \\
\hline $\begin{array}{l}\text { I'Sawdust } \\
\text { I I Chips - - }\end{array}$ & 930000 & power and heat & 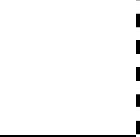 & 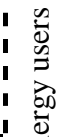 \\
\hline 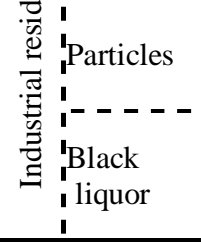 & $\begin{array}{ll}\text { i } & \\
\text { i } & \\
\text { I } & \\
\text { i } & 557000 \\
\text { I } & \\
\text { I } & \end{array}$ & $\begin{array}{r}\text { Industrial } \\
\text { internal }\end{array}$ & 1246000 & $\begin{array}{l}\text { Iี } \\
\vdots \\
\vdots \\
\vdots \\
1\end{array}$ \\
\hline Total & 8731739 & & 5890000 & \\
\hline
\end{tabular}

On the other hand, the lowest ratio (1.4) was determined for roundwood needed for the production of particleboard. The industry produced an output of 0.52 mil. $\mathrm{m}^{3}$ and from the viewpoint of raw material utilisation, it belongs to the industries with the lowest rates of residue production. 
MATERIAL FLOWS IN PRIMARY WOOD PROCESSING IN SLOVAKIA

Ján Parobek; Hubert Paluš

\section{Conclusions}

Wood residues and by-products are produced during industrial processing of wood. The waste stream is represented by different types of waste generated during the logging operations (e.g., logging residues) as well as the waste generated during primary mechanical and chemical processing of wood (sawdust, chips, black liquor), which can be used either industrially or for the production of energy. The primary source of wood residues used for production of agglomerated wood-based panels, processed fuel wood, and energy generation is the sawmilling industry.

Wood balance is primarily used to estimate domestic consumption, regardless of the further use of wood; unlike the wood resource balance, it considers foreign trade in wood products. Taking into account roundwood classification, the wood resource balance distinguishes wood flows for individual sectors according to the intended use of assortments. Logs are primarily processed by sawmills, and only a small portion is consumed by plywood or veneer producers.

As a paradox, in spite of the large proportion of broadleaved forests in Slovakia, coniferous logs are the primary raw material used by sawmills. Non-coniferous pulp wood and other industrial roundwood is used by the pulp and paper industry for the production of pulp, or alternatively for the production of particleboard and fibre board.

The importance of wood for energy production has been increasing recently. Wood fuel is used for energy production in either internal or external facilities. At the same time, it represents a significant source for heat energy in households. Wood, which was traditionally utilised as material for the production of wood products, is presently in demand for energy production. The increasing direct or derived demand for energy wood causes an increase in energy wood prices.

\section{Acknowledgements}

The authors are grateful for the support of the Scientific Grant Agency of the Ministry of Education, Science, Research, and Sport of the Slovak Republic, Grant No 1/0473/16, "Dynamics and determinants of wood based products market in the Slovak Republic".

\section{References}

[1] PAROBEK, J., PALUŠ, H.: Modelling of wood and wood products flow in the Slovak Republic," in: $A$ European Wood Processing Strategy: Future Resources Matching Products and Innovations, Ghent University, Belgium, pp. 93-99, 2008.
[2] EUROSTAT: Economy-wide material flow accounts and derived indicators: A methodological guide, retrieved from: http://epp.eurostat.ec.europa.eu/cache/ITY_OFFPUB/ KS-34-00-536/EN/KS-34-00-536-EN.PDF, 2001.

[3] BINDER, C. R., HOFER, C., WIEK, A., SCHOLZ, R. W.: Transition towards improved regional wood flows by integrating material flux analysis and agent analysis: The case of Appenzell Ausserrhoden, Switzerland, Ecological Economics 49(1), pp. 1-17, 2004.

[4] FISHER-KOWALSKI, M.: Society's metabolism, the intellectual history of material flow analysis, Journal of Industrial Ecology 2(1), pp. 61-78, 1998.

[5] HINTERBERGER, F., GILJUM, S., HAMMER, M.: Material flow accounting and analysis (MFA): A valuable tool for analyses of society-nature interrelationships, retrieved from: http://seri.at/wpcontent/uploads/2009/09/Material-Flow-Accountingand-Analysis-MFA.-Encyclopaedia-of-theInternational-Society-for-Ecological-EconomicsISEE.pdf, 2003.

[6] ZHOU, Z., SUN, L.: Preliminary research on regional material flow analysis: A case study of Chengyang District in Qingdao, Journal of Northeast Agricultural University 15(2), pp. 41-47, 2008.

[7] BRINGEZU, S.: Industrial ecology and material flow analysis. Basic concepts, policy relevance and some case studies, in: Perspectives on Industrial Ecology, D. Bourg and E. Suren (eds.), Greenleaf Publishing, Sheffield, UK, pp. 24-30, 2003.

[8] BACCINI, P., BADER, H. P.: Regionaler Stoffhaushalt. Erfassung, Bewertung und Steuerung, Spektrum, Heidelberg, Germany, 1996.

[9] MÜLLER, D.: Szenarien zur nachhaltigen regionalen Holzbewirtschaftung, Schweizerische Zeitschrift für Forstwesen 147(11), pp. 873-885, 1996.

[10] SCHWARZENBACH, R. C., HEITZER, A., STÄUBLI, B., GROSSMANN, B., SCHOLZ, R. W.: A regional perspective on contaminated site remediation - Fate of materials and pollutants, Environmental Science and Technology 33(14), pp. 2305-2310, 1999.

[11] HEKKERT, M. P., JOOSTEN, L. A. J., WORRELL, E.: Analysis of the paper and wood flow in the Netherlands, Resources, Conservation and Recycling 30(1), 29-48, 2000.

[12] PIŠKUR, M., KRAJNC, N.: Roundwood flow analysis in Slovenia, Croatian Journal of Forest Engineering 28(1), pp. 39-46, 2007.

[13] KNAGGS, G., O'DRISCOLL, E.: Estimated woodflow for the Republic of Ireland in 2007, retrieved from:

http://www.coford.ie/media/coford/content/publicati ons/projectreports/cofordconnects/woodflow.pdf, 2008. 
[14] MANTAU, U., SAAL, U., PRINS, K., STEIERER, F., LINDNER, M., VERKERK, H., EGGERS, J., LEEK, N., OLDENBURGER, J., ASIKAINEN, A., ANTTILA, P.: EUwood real potential for changes in growth and use of EU forests, retrieved from: http://ec.europa.eu/energy/renewables/studies/doc/bi oenergy/euwood_final_report.pdf, 2010.

[15] FAO: FAOSTAT - Forestry, retrieved from: http://faostat.fao.org, 2015.

[16] MARD: Zelená správa 2014, retrieved from: http://mpsr.sk/sk/download.php?fID=7840, 2014.

[17] UNECE/FAO: Forest Product Conversion Factors for the UNECE Region, ECE/TIM/DP/49, UN, Geneva, 2010.

\section{Review process}

Single-blind peer reviewed process by two reviewers. 